\title{
Economic development and social policies in Mexico
}

\author{
Juan Carlos Moreno-Brid, \\ Juan Ernesto Pardinas Carpizo and Jaime Ros Bosch
}

\begin{abstract}
Since the mid-1980s Mexico has implemented a radical reorientation of its development strategy away from state-led industrialization and trade protection. This reform has drastically reduced the role of the state in the economy in favour of market mechanisms, and changed the orientation of social policies towards targeting and decentralization. The article examines the effects of this reform on Mexico's social and economic development, and finds that its results have been far from stellar. Indeed, notwithstanding the reduction of inflation and the downsizing of the state, the economy has expanded at a slow rate way below its growth in needs. The authors conclude that if Mexico is to succeed in its quest to enter a path of robust long-term development it will need to modify its social and economic policies.
\end{abstract}

Keywords: social policies; Mexican economy; economic development; social development; neoliberal reforms; NAFTA.

\section{Introduction}

Over the twenty-five years since the international debt crisis of 1982 Mexico has been involved in a radical reorientation of its development strategy. This process has had consequences not only for its economic policy but also for

Juan Carlos Moreno-Brid, ECLAC, Av. Presidente Masaryk 29 Piso 13 Col. Chapultepec Morales, México D.F. CP 117520.E-mail: juancarlos.moreno@cepal.org

Juan E. Pardinas, Instituto Mexicano para la Competitividad, Leibinitz 11, piso 6, desp. 602,Col. Anzures CP 11590,México.E-mail: juan.pardinas@imco.org.mx

Jaime Ros Bosch, 319 Hesburgh Center, Kellogg Institute for International Studies, University of Notre Dame, Notre Dame, Indiana 46556,USA. E-mail: ros@nd.edu 
social welfare. Mexico's abandonment of its traditional development model based on import substitution and state-led industrialization was also accompanied by a shift from policies aimed at universal welfare provision. In its place it adopted a neo-liberal agenda of trade and financial liberalization, a reduced role for the state in the economy and the introduction of social policies based on means-tested, targeted programmes. Government officials, as well as a number of mainstream economists, argued at that time and well into the 1990s that reforming economic and social policies was essential if Mexico was to achieve rapid and sustainable economic growth along with a substantial reduction of poverty.

As is by now well known, these expectations were not fulfilled, although the reforms did result in annual inflation stabilizing at single digit levels, while the budget deficit was also eliminated. However, Mexico's growth has been sluggish and subject to periodic financial crisis, and it has failed to create the number of jobs required by the labour force - estimated at between 800,000 and one million per year. The very limited expansion of employment that has occurred has put enormous pressure on the system, exceeding the capacities of the targeted social policies to improve significantly the living standards of the vast proportion of the population living in poverty. In fact, as we argue in this and other contributions, the reduction of poverty achieved in the last ten years has been determined much more by the increase in the proportion of economically active population - associated with Mexico's demographic transition - than by the impact of social policies including those aimed at relieving poverty through cash transfers. While these programmes of targeted social expenditure have improved the education and health indicators of many poor families, they are not able fully to compensate Mexican society for the adverse social consequences of the slow expansion of employment and economic activity. Indeed, given Mexico's slow economic growth, it may be argued that without the 'demographic bonus' even the best-designed, bestfunded and best-administered social policies would fail to bring significant improvement in the living standards of the poor. The purpose of this article is to present the main characteristics of Mexico's shift to neo-liberal economic and social policies and to examine their overall impact. The Mexican case has been seen as a paradigmatic example of a drastic and thorough implementation of the neo-liberal reform agenda, so it is important to identify some reasons why these reforms failed to meet the expectations that accompanied their introduction in the mid-1980s.

As we shall argue, the downsizing of the Mexican state led to a contraction of public investment that was not compensated for by the private sector. The consequent collapse of the investment ratio made it more difficult to modernize and expand the capital equipment necessary to increase the international competitiveness of the domestic economy. The tendency of the real exchange rate to rise contributed to a worsening of the growth potential of the export sector. In this context of an overall economic slowdown and poor employment performance, Mexico's social policy seemed to be running up 
a down escalator, having to deploy additional resources just to keep pace and so avoid a massive deterioration of social conditions. ${ }^{1}$ A key characteristic of the Mexican case, shared by most Latin American countries in the 1990s, is that the neo-liberal reforms failed to put the economy on a path of sustained and robust expansion. In these conditions, social polices were incapable of fully compensating for the adverse effects of the economic slowdown and the lack of job opportunities.

\section{Background: Mexico's traditional economic development strategy (1950s-81)}

In the period after the Second World War, Mexico's pursuit of economic development relied upon public sector intervention to foster industrialization via import substitution industrialization (ISI). This economic strategy was complemented by social policies aimed at universal coverage of basic social services - health, education, water and sanitation. ISI strategy was designed to protect Mexico's domestic market for manufactures from the pressure of the competition of imports. Trade protection was achieved by applying tariff duties on imports, by imposing the requirement of permits prior to importation and by prohibiting the entry to the domestic market of a wide variety of imported goods. In turn, direct foreign investment was strictly regulated, being accepted as a minority partner in some areas while it was excluded in so-called strategic areas.

In addition, active industrial policies and subsidies were used to strengthen the manufacturing industry, especially in the production of consumer and intermediate goods (Ros, 1994). ${ }^{2}$ Other channels through which manufacturing received additional and special support from the government included: 1 ) high wholesale domestic prices for final products due to trade protection; 2) subsidized, low-cost energy and other utilities; and 3) easy access to credit from development banks and tax exemptions on certain imports of machinery and equipment (Moreno-Brid \& Ros, in press). An original element of Mexico's ISI strategy was the Maquiladora programme. It was put in place to stimulate, through tax exemptions and import incentives, the establishment of labour-intensive, in-bond assembly plants along the northern border region situated to favour exports to the United States. Finally, during these decades many public enterprises were created in order either to intervene in key markets or to avert the bankruptcy of certain private firms and thus to protect employment (Rogozinsky, 1996). ${ }^{3}$

In the late 1970s, Mexico's economic expansion lost momentum as the ISI strategy entered the phase of attempting to substitute imports of hightechnology machinery and equipment at the same time as the world economy slowed due to the oil shocks. In 1977 the Mexican government launched an ambitious development programme funded by the vast inflow of oil revenues and external debt. The programme boosted Mexico's economy. In 1977-81 its 
real GDP expanded at an average annual rate that was over and above 8 per cent, but fiscal and foreign exchange revenues became critical and increasingly dependent on petroleum exports as imports of intermediate and capital goods soared. The collapse of the international oil market in 1981 coupled with the rise in US interest rates triggered a balance of payments crisis in Mexico that forced President López Portillo to declare a moratorium in August 1982 on external debt service payments. This action ended nearly forty years of Mexico's steady economic expansion and ultimately led to the demise of ISI and the abandonment of state-led industrialization.

It was, however, acknowledged that ISI and its social policies had positive impacts on Mexico's development. Indeed, in its four decades of implementation, Mexico's per capita real GDP grew at an annual average rate over and above 3 per cent. Such dynamism, essentially driven by the impulse of manufacturing industry, transformed Mexico from an agrarian to an urban, semi-industrial society, and the incidence and depth of poverty decreased. However, notwithstanding such merits this strategy had been unable to remove key obstacles on Mexico's road to development. The first was the unequal distribution of the benefits of economic growth. Indeed, despite four decades of continuous economic expansion, the distribution of income and wealth in Mexico remained extremely uneven and poverty still stood at unacceptably high levels.

A second obstacle was that, with the exception of the Maquiladora and the special development programmes applied to a few industries, the strategy had not been able to build a strong non-oil export sector or a competitive domestic capital goods industry. The third was the failure to implement fiscal reform that would strengthen tax revenues and thus reduce the public sector's dependence on oil and external debt. Weak fiscal revenues reflect a weak public sector and state. A fourth obstacle was that social policies were never backed by sufficient fiscal revenues to be able to achieve the goal of universal protection of basic needs for the rapidly expanding population. Moreover, the design and benefits of social insurance schemes were tightly linked to the evolution of formal employment, ${ }^{4}$ marked by an inadequate system of pension and health contributions that did not guarantee their long-term solvency. All these limitations proved fatal.

\section{The end of ISI and the shift to neo-liberalism}

The government of Miguel de la Madrid (1982-8) initiated the process of radical macroeconomic reform, with policies of trade and financial liberalization, market deregulation, privatization and the sharp reduction of the state's intervention in the economy. By the mid-1980s, numerous tariff and non-tariff restrictions on imports were removed, and Mexico had become a full member of GATT. Public expenditure was slashed. President Salinas de Gortari's administration (1988-94) accelerated these reforms by rapidly and 
significantly opening the domestic financial market to foreign competition, carrying out a vast wave of privatizations of public enterprises (including the sale of the telephone company and the domestic banking system) and eliminating many restrictions on FDI in manufacturing except in the production of explosives and basic petrochemicals (Clavijo, 2000; Moreno Brid \& Ros, in press).

The jewel in President Salinas' drive to deepen economic liberalization was the launch of the North America Free Trade Agreement (NAFTA) between Mexico, Canada and the United States in $1994 .{ }^{5}$ It went into effect on 1 January 1994, eliminating, over the next ten to fourteen years, virtually all tariff and non-tariff barriers to intra-regional trade and further easing restrictions on FDI. NAFTA formally institutionalized Mexico's trade liberalization and gave it a long-term perspective. Since then Mexico has joined the OECD and the WTO, and has signed free trade agreements with numerous countries, including Chile (1991), Costa Rica (1994), Colombia, Venezuela (1994), Bolivia (1994) and Japan (2004). Today, except for phytosanitary regulations, Mexico keeps very few trade restrictions. In fact, in 2008, all non-tariff restrictions on trade on agricultural goods, including maize, were lifted.

The reforms brought about a fundamental shift in industrial policy, eliminating all sectoral development programmes and substituting them with so-called 'horizontal' policies applied across the board. Credit and tax subsidies, trade protection schemes and other policies aimed at strengthening selected industries or sectors were cancelled. Instead of trying to 'pick winners', the new policy focused on simplifying administrative procedures, cutting red tape and speeding up tax deduction of depreciation allowances (Clavijo, 2000). Presidents Zedillo (1994-2000) and Fox (2000-6) advocated a certain reorientation of industrial policy. Though explicitly rejecting any notion of going back to trade protectionism, they argued that trade liberalization had led to an excessive delinking of some productive chains in the Mexican manufacturing sector. They concluded that some sectoral-specific programmes were required to increase Mexico's international competitiveness. However, their exhortations ended up being merely rhetorical as they failed to allocate sufficient funds to create and implement such programmes.

It is too early to assess Calderón's administration (2006-12) but so far it has followed a similar macroeconomic strategy to its predecessors - namely, it is committed to NAFTA and fiscal balance - while still shying away from active industrial policies. It should be noted, however, that at the beginning of 2008 the President and the Minister of Finance announced the launch of a strong public investment work programme geared at trying to reduce the impact of the adverse external shocks caused by the slowdown of the US economy. How significant will this programme be in practice? Will it imply a change in policy towards a renewed, more active participation of the state in modernizing infrastructure and thus strengthening the international competitiveness of the Mexican economy? These are still open questions. 
In Mexico, as elsewhere in Latin America, the economic reforms were accompanied by changes in social policy, in terms of their goals as well as in their key instruments. As noted, social policies were previously centred on gearing public expenditure and subsidies to expanding the supply of health, education and other basic services premised on an ambitious but far from realized goal of guaranteeing universal social protection. Such social protection tended to be strongly dependent on the formal employment of the beneficiaries. The reforms were gradually reoriented to subsidizing demand, with an emphasis on focusing social expenditure on a targeted sector of the population in poverty. The government also began to rely on conditional cash transfers to increase the human capital of the poor in the hope of improving their long-term labour and economic prospects. ${ }^{6}$ Though their human capital has certainly improved through these initiatives, the latter expectations concerning their better insertion in the labour market are yet to be fulfilled.

\section{Mexico's economy after the neo-liberal reforms}

\section{The positive outcomes: low inflation and booming exports}

The neo-liberal macroeconomic reforms together with NAFTA had positive effects on Mexico's fiscal performance, domestic inflation and participation in global markets. As is amply documented, the reduction of state intervention in the economy was also marked by a slashing of public investment and a strong commitment to avoid fiscal deficits. However, the federal government's fiscal revenues remained weak. In 2007 they represented only 12 per cent of GDP when oil is excluded, and $\mathbf{1 7 . 5}$ per cent if it is included, revealing a heavy dependency on oil income. Monetary policy tends to maintain a constant nominal exchange rate which helps to reduce inflationary expectations but leads to persistently overvalued real exchange rates.

The macroeconomic reforms undoubtedly had a significant impact on Mexico's foreign trade. On the one hand, exports soared after their implementation, and their composition changed dramatically. Indeed, in the late 1970s Mexico was basically an oil-exporting economy, but by 1988 manufactures provided more than 50 per cent of total exports. Today, even though the price of crude petroleum oil has significantly increased the share of oil exports, the share of manufactures in total exports exceeds 80 per cent (see Figure 1).

Parallel to this export boom, there has been a surge in imports. In fact, applied econometric studies reveal that in the last fifteen to twenty years Mexico's economy has significantly increased its structural dependence on imports (see, inter alia, Pacheco-López, 2005; Moreno-Brid, 2001, 2002). The results indicate that in the last twenty years Mexico's long-term 'income elasticity' in the demand for imports has more than doubled. Traditionally its 


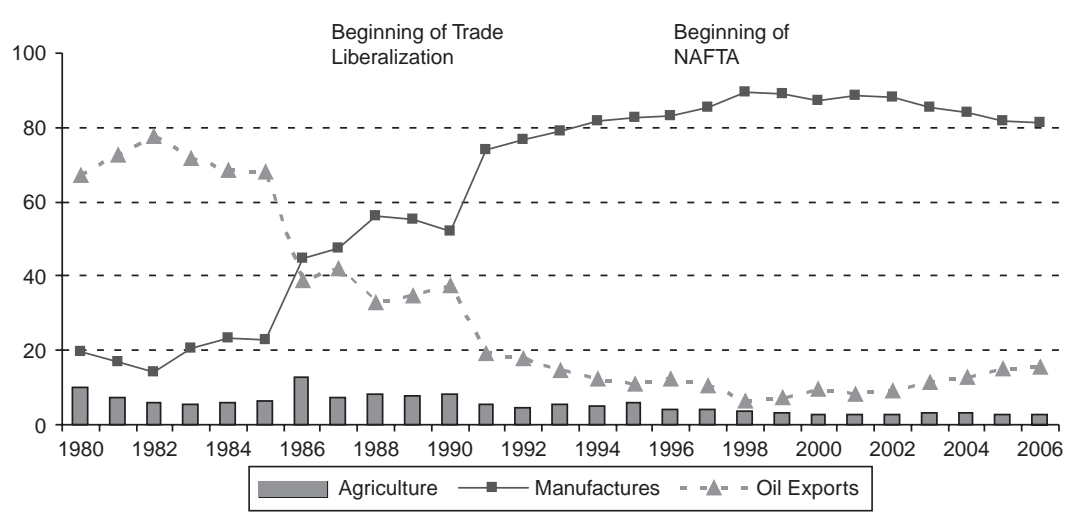

Figure 1 Composition of total exports, Mexico 1980-2006 (\%)

Source: Authors' elaboration based on INEGI (2007).

value stood between 1.2 and 1.5 , but it has since risen to levels close to 3.0. This implies that if Mexico's real income is to grow at an annual average longterm rate of 5 per cent, its imports in real terms would tend to expand by 15 per cent. To keep the trade deficit in check as a proportion of income, Mexican exports should expand by at least 15 per cent per annum. Such rapid export growth seems unlikely to be sustained in the long run, especially now that the US economy is experiencing a slowdown that could be long-lasting. Given this binding external constraint, it should not come as a surprise that Mexico's economic growth after the macroeconomic reforms has been disappointing. In fact, its real gross domestic product (GDP) expanded during 1990-2006 at an average rate way below its historical average in 1950-80. Moreover, it has remained incapable of generating sufficient jobs.

Figure 2 illustrates how trade liberalization along with other macroeconomic reforms has failed to put Mexico on a path of strong export-led growth. It shows that, for the economy as a whole, the relation between trade performance (measured by the trade deficit as a percentage of GDP) and economic growth has deteriorated. Indeed, during 1971-81, Mexico's real GDP expanded at an annual average rate of above 7 per cent and registered a trade deficit of 2.7 per cent. The collapse of the oil boom forced an economic slowdown in the 1980s concomitant with a significant trade surplus. The first years after NAFTA excluding 1995 - saw real GDP expand at more than 5 per cent annual average. This recovery was short-lived. The real appreciation of the peso and the slowdown of the US economy in 2001 put an end to the dynamism of this short period of export-led growth. Moreover, in 2001-6, the Mexican economy barely grew (less than 3 per cent on an annual average rate), registering a trade deficit of close to 1 per cent. In other words, although exports have been extremely dynamic since the reforms, they have been increasingly unable to pull the rest of the Mexican economy along a path of strong expansion. This is starkly illustrated by the evolution of its income per capita relative to the US. As 


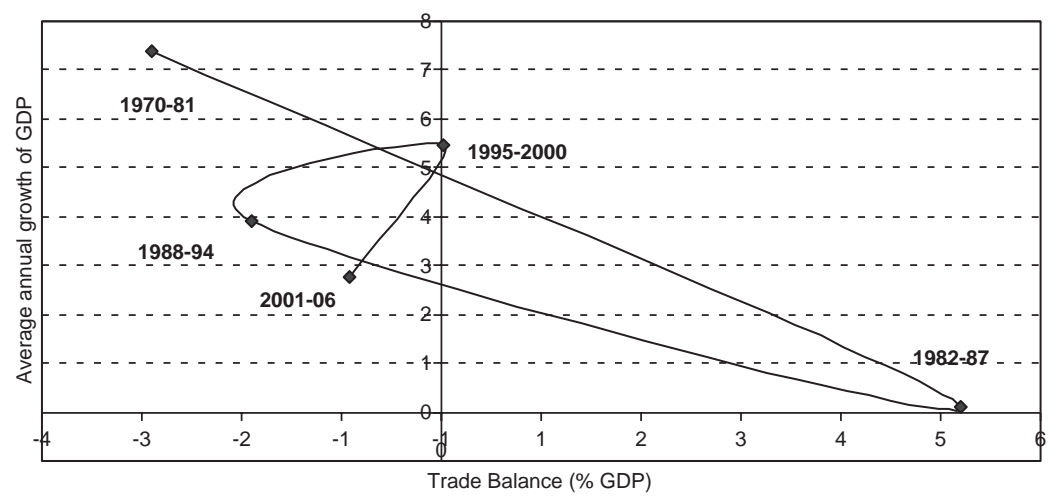

Figure 2 Trade balance and real GDP growth in Mexico, 1970-2006

Figure 3 shows, in the early 1980s the gap between the two countries widened. While it narrowed slightly in the late 1980s, it widened again after the economic crisis of 1995. Since then, notwithstanding the macroeconomic reforms, it has not recovered and in 2006 stood at a level comparable to that of the 1950s.

Summing up, Mexico's shift towards a neo-liberal strategy has had mixed but rather disappointing results. On the positive side, it did help to reduce the fiscal deficit and to achieve stable, low rates of inflation. It brought about a surge of non-oil exports and of foreign direct investment. Indeed, in the last twenty-five years Mexico went from being just an oil-exporting country to becoming a major export platform of manufactured goods, including vehicles, auto parts, ready-made clothing and electronic products, to the United States. But on the negative side, overall economic growth has been too slow. Moreover, the various foreign exchange crises have prevented the consolidation of a sustained and robust economic expansion.

Part of the explanation for this failure lies in the fact that an overall upturn in investment did not accompany the reforms associated with the new macroeconomic environment. Indeed, fixed capital formation has remained at a level equivalent to less than 22 per cent of GDP. This percentage is way below the 25 per cent benchmark identified by UNCTAD as the minimum investment ratio required to sustain a medium-term annual economic expansion of 5 per cent. This lack of investment is to a certain extent explained by the sharp fall in public investment.

In addition, although financial liberalization brought about a deep restructuring of Mexico's banking sector, domestic credit availability for productive activities and investment has been severely rationed for the last ten years. As a share of GDP, banking credit to support productive activities shrank between 1996 and 2006 by more than 15 points. Thus Mexico's economy has been acquiring the characteristics of a dual structure. There are a few very large firms and activities whose links with transnational corporations and easy access to foreign capital have helped them to become relevant players 


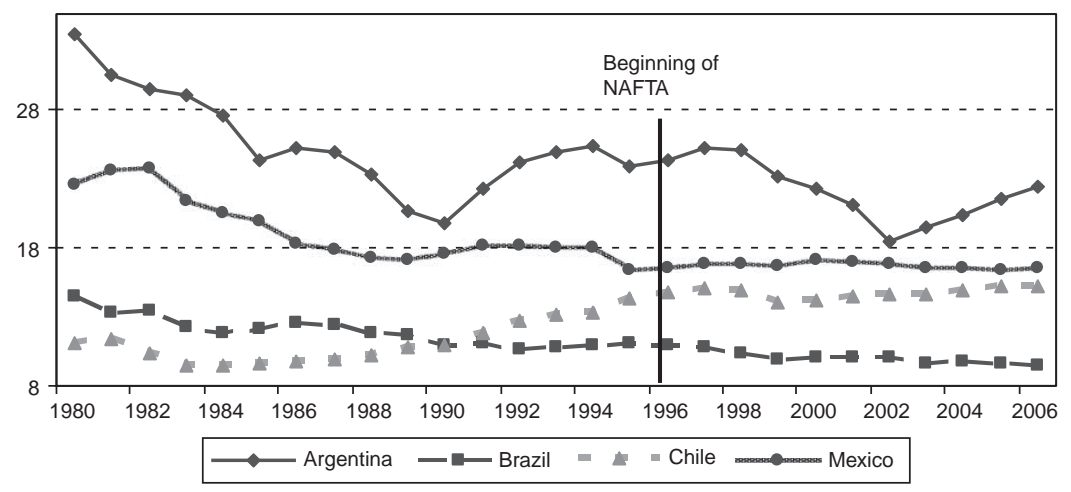

Figure 3 Mexico and other countries: real GDP per capita (relative to the USA) 1980-2006 (USA GDP per capita $=100$, measured in constant 2000 US\$)

Source: Own elaboration based on World Bank, World Development Indicators (2006).

in world markets. But there is a vast number of medium and small firms and thus a large informally-employed population, struggling to survive the intense pressure from their external competitors.

Job creation in Mexico after the reforms has been disappointing. There has been some re-composition in favour of export-related activities but, all in all, employment growth has been far from dynamic. In 2006, open unemployment reached its highest level in years, with a vast proportion of the employed being accounted for by the informal sector. The earnings and wage gap between the qualified and the unqualified labour force has widened. The weak labour absorption capacity of the economy has fuelled migration flows to the US, with approximately 400,000 Mexicans - in net terms - migrating abroad each year.

\section{Key aspects of Mexico's social policies after NAFTA}

After the cancellation of some social programmes put in place during the oil bonanza and drastic cuts in public social spending throughout the severe external and fiscal crises faced by the De la Madrid administration (1982-8), social policy became a key axis of the Salinas administration's political strategy (1988-94). Fiscal expenditure has since been reoriented to social development. ${ }^{7}$

Table 1 shows selected indicators of Mexico's public expenditure on social development and poverty alleviation for the Zedillo (1995-2000) and the Fox administrations (2001-6). This shows that in both periods government expenditure on the social sector expanded at a faster rate than real GDP. Its pace, however, slowed down from 6.6 per cent in 1995-2000 to 3.7 per cent in 2001-6. This also indicates that social spending rose as a share of GDP from an average of 8.9 per cent to 10.1 per cent. This increase in social spending has not been concentrated solely in the programmes earmarked for poverty 
Table 1 Mexico: selected indicators of public expenditure in social development 1995-2000 vs. 2001-6

\begin{tabular}{lcc}
\hline & $1995-2000$ & $2001-6$ \\
\hline Real GDP growth (average, \%) & 3.5 & 2.4 \\
Public expenditure: social development & 8.9 & 10.1 \\
$\quad$ (\%, GDP) & 6.6 & 3.7 \\
$\quad$ (average annual growth, \%) & 1.1 & 1.4 \\
\hline
\end{tabular}

Source: Cabrera (2007), based on official data.

alleviation. Indeed, as a share of GDP, these latter expenditures rose from a low average of 1.1 per cent of GDP in the Zedillo administration to an average of 1.4 per cent under Fox.

The increase in public expenditure for social development has been a feature common to the Latin American region over the last two decades (CEPAL, 2004) ${ }^{8}$ In Mexico, although the increase was slightly higher than the average in the region, social spending as a proportion of GDP is still below Latin America's average. Moreover, it falls way short of guaranteeing universal protection or coverage in the social security system. Today the majority of Mexican households do not have a single member enrolled in the social security system. As Diaz Cayeros, et al. (2008), quoting a World Bank study, state: ' 75 per cent of the non poor, 39 per cent of the moderately poor and zero per cent of the extreme poor are covered either by the Instituto Mexicano del Seguro Social (IMSS) or by the Instituto de Seguridady Servicios Sociales de los Trabajadores del Estado (ISSSTE).'

What lies behind this increase in social expenditure in Mexico? On the one hand privatization, deregulation and the elimination of industrial policies brought about by the neo-liberal reforms gave room for an increase in public expenditure for social purposes. In addition, the resumption of economic growth, however modest, since the early 1990s brought more fiscal revenues and thus increased the resources that could be devoted to meet social needs. Finally, there has been increased pressure from civil society to allocate more resources to ameliorate the living conditions of the poor population after the severe deterioration suffered during the 1980s. This pressure may have increased pari pass $u$ with the deterioration in employment prospects. In any case, as in the rest of Latin America, Mexico's transition to more democratic forms of government since the late 1990 s went along with a strengthening of social policy as well as of special programmes oriented to alleviation of poverty. ${ }^{9}$

\section{The education challenge}

Public education is a cornerstone of Mexican social policy and the most important in terms of government social expenditure. For 2006, the allocation 
for the Ministry of Public Education represented 6.9 per cent of the total federal budget. If we take into account the funds allocated to the federal entities and municipalities the percentage rises to 9.2. When combined with resources invested by the private sector in education, Mexico's total expenditure on education is today equivalent to approximately 6.6 per cent of its GDP.

Although education policy has not reached its full potential as a tool for poverty reduction, recent data confirm some progress. The number of student enrolments, (preschool to postgraduate studies), jumped from 13 million in 1970 to 32 million in 2002. In the same period, the average number of years of school attendance rose from three to seven. Children who started elementary school in 2002 are expected to complete, on average, eleven grades of school, a significant increase over the 2.6 grades completed in 1960. Despite good coverage for basic education, demographic changes are placing enormous demands on high school and university education. Mexico needs to invest massive resources in order to widen the coverage of higher education. The other challenge is to improve the quality of Mexico's public education system. The Programme for International Student Assessment (PISA) test for 2003 was taken by more than a quarter of a million students in forty-one countries, to asses their skills in mathematics, reading, science and problem-solving (OECD, 2003). On average, Mexico ranked thirty-eighth in the three sections of the test. In mathematics, Mexico was placed in the bottom group with 375 points, way below the top performers: Korea and Finland (550 points). Moreover, only one-third of the group of 15-year-old students who participated in the PISA test 2003 had adequate basic skills in mathematics.

Mexico's poor results are explained not so much by the quantity of resources it dedicates to education as by its inefficiency in using them. Indeed, in 2003, Korea's total expenditure in education - by the public and the private sectors was equivalent to 7.5 per cent as a proportion of GDP. Mexico's was somewhat lower at 6.8 per cent, but more than two points higher than Spain's (4.7 per cent) and Ireland's ( 4.4 per cent). However, the latter two countries' average scores in mathematics were more than 100 points higher than Mexico's. The OECD study reveals that, of Korea's total expenditure in education in 2003, 59 per cent was carried out by the public sector and 41 per cent by the private. In the US, the share of the public sector was 72 per cent, and in Mexico it was even higher at 82 per cent, with Spain at 89 per cent and Ireland at 93 per cent. In addition, Mexico shows marked differences in the composition of public expenditure (between current and fixed capital formation) compared to the other countries. While in Mexico only 3 per cent is dedicated to investment (i.e. 97 per cent is current expenditure), in Ireland it is 8 per cent, in Spain 9 per cent and in Korea 19 per cent.

On the other hand Mexico and Slovakia are the countries with the smallest expenditures on education. Data from the OECD show that Mexico spends an average of US $\$ 15,000$ (measured at constant purchasing power parity) to cover education from age 6 to 15. Greece spent twice as much; Ireland, Korea, Spain 
and Portugal three times as much; Italy, Denmark, the United States, Switzerland more than five times as much (OECD, 2004). The 2003 PISA results suggest that most Mexican children are not receiving sufficiently high educational skills to bring their human capital up to international standards. Thus public and even private education are in danger of failing to break the inter-generational cycle of poverty.

\section{Other key elements of social expenditure in Mexico}

As in the rest of Latin America, programmes of targeted conditional cash transfers have proliferated in recent times. Pronasol was the first of this kind in Mexico. It was established by the Salinas administration as a national antipoverty programme to offer funds for public works conditional on the beneficiary communities' active participation and on municipal or state governments' cooperation through matching grants. This programme was marked by discretionary, publicized allocations of public spending in selected poor regions. It was used by President Salinas to exploit the political gains of social expenditure. Indeed, his government sought to legitimize its revolutionary credentials with Pronasol and to strengthen the control of the ruling party (the Partido Revolucionario Institucional) over the results of the electoral processes (Diaz Cayeros et al., 2008). However, when President Salinas's popularity collapsed with the 1994-5 foreign exchange crises, Pronasol was harshly criticized and seen as a political manoeuvre designed to buy the votes of the poor.

In 1997, the Zedillo administration replaced Pronasol with Progresa, a human development scheme that combined cash transfers to poor households in rural areas conditional on their children attending local schools and the family attending regular checks at regional health clinics. These conditional cash transfers and the selection of beneficiaries are calculated on a formulabased targeting scheme, and given to the woman of the household independently of whether or not she is its head. In 2002 President Fox changed the programme's name to Oportunidades. He retained the multidimensional approach of targeted subsidies combined with obligatory school attendance and medical clinic visits, but introduced some changes. He widened the programme's coverage to include urban areas and also subsidized three more years of education, thus covering elementary, junior high and high school (twelve years of education), just short of university. A third change was the creation of the spin-off programme Jóvenes con Oportunidades (Youngsters with Opportunities), which provided a savings account for children of beneficiaries if they were performing satisfactorily in the last three years of high school. The funds could be accessed only after graduation in the hope that they would assist in meeting the costs of university or of opening a small business. The number of beneficiaries of Oportunidades jumped from 2.5 million families in 2000 to 5 million after 2004, with 68.8 per cent of the 
beneficiaries located in rural areas, 17.2 per cent in semi-urban regions and 14 per cent in urban centres. By 2006, the beneficiary households were receiving an average transfer of US $\$ 45$ per month. The programme also provided nutritional supplements for pregnant and breast-feeding mothers, as well as for children under the age of 5 .

Independent evaluations have systematically confirmed the positive and significant impact of Oportunidades in improving the nutrition, health and education of its beneficiaries (see, inter alia, de Janvry \& Sadoulet, 2006; Behrman, Sengupta \& Todd, 2002). In 2006 Mexico's National Institute of Public Health prepared an independent evaluation whose major findings are summarized in Table 2. Every three years there is a verification process to investigate whether beneficiary families are still meeting its targeting requirements. The 2006 exercise concluded that 20,000 families had, so to speak, graduated from Oportunidades. They stopped living in poverty and had incomes high enough to satisfy their food, health and education needs. This number represents barely 0.4 per cent of the total of 5 million families covered by Oportunidades, a rather low percentage for the programme to be considered an effective instrument in eradicating poverty. Even if the percentage of 'graduation' were five times higher, i.e. 2 per cent, it would imply that, ceteris paribus, this transfer scheme would take at least five decades to eradicate poverty. ${ }^{10}$

Table 2 Evaluation of Oportunidades 2006

\begin{tabular}{ll}
\hline Area & \multicolumn{1}{c}{ Achievements } \\
\hline Education & $\begin{array}{l}\text { Reduced fail and drop-out rates, and improved likelihood of students } \\
\text { (especially females) continuing their education from elementary to high } \\
\text { school and from high school to college. Improved educational } \\
\text { achievement and greater willingness of parents to promote continuous } \\
\text { schooling for their children and the fulfilment of their school obligations. } \\
\text { (The positive effects were usually greater for girls). } \\
\text { Reduced mortality rates in mothers and children. Municipalities } \\
\text { incorporated in the programme reported on average lower rates (11\% and } \\
\text { 2\%, respectively). Large increase in the use of public outpatient health } \\
\text { services for all ages and reduction in the use of private services, thus } \\
\text { generating savings for beneficiaries. } \\
\text { Reduction in the high proportion of anaemia. Increase of height and } \\
\text { weight of children in their early years. } \\
\text { Children aged } 24 \text { to } 71 \text { months in the beneficiary communities grew on } \\
\text { average somewhat more than the control group, and the high proportion of } \\
\text { low weight was reduced by } 12.4 \% \text { Incidence of anaemia was reduced in } \\
\text { rural children of } 2 \text { and } 3 \text { years. The motor abilities of girls and boys from } 3 \\
\text { to } 6 \text { years increased by } 10 \% \text { and } 15 \% \text {, respectively, and there was an } \\
\text { improvement of } 9 \% \text { in the social behaviour of girls. } \\
\text { Improvement in the diet of beneficiary households, allowing them to buy } \\
\text { products of animal origin and provision of nutritional supplements for a } \\
\text { large proportion of children. }\end{array}$ \\
\hline
\end{tabular}

Source: Cruz, de la Torre \& Velázquez (2006). 
The improvements in education and in nutrition due to this programme are apparently increasing the capabilities and human capital of beneficiary children. Such benefits, however, are not automatic but depend in particular on the quality of the education received. If the school does not have adequate infrastructure, good and motivated teachers and educational material, the merits of the conditional cash transfer programme as far as human capital formation is concerned are questionable. In any case, whether these changes are significant or sufficient to guarantee the beneficiaries better access to quality jobs that may enable them to escape poverty is an

open question. Moreover, the answer depends not so much on Oportunidades per se, but on whether the Mexican economy can grow rapidly and create enough jobs. So far this has not occurred and, given the current economic situation in the United States, it is unlikely to occur in the short and medium term.

Oportunidades has improved the human capital of many poor families and has reduced, though not necessarily eliminated, the politically discretionary character of transfers to poor families. However, its impact on reducing longterm poverty, as evidenced by the low rates of 'graduation' of poor families among its beneficiaries, seems to be insignificant. In any case, it would be erroneous to expect that a poverty alleviation programme would significantly reduce the incidence or depth of poverty in an economy with the features characteristic of that in Mexico. In these conditions, no social programme by itself will significantly improve the living conditions of the poor. Apart from the need for sustained levels of growth required to produce the conditions that would break the inter-generational cycle of poverty, many more resources need to be allocated to poverty reduction, and this is unlikely given insufficient fiscal revenues, inefficiencies in their allocation and, crucially, the persistent deterioration in the conditions of employment due to the lack of dynamism of the Mexican economy. Insufficient public funding is and will be an obstacle for some years to come, unless another fiscal reform is implemented.

\section{Social development in Mexico under two different development strategies}

Poverty

Figure 4 depicts the evolution of poverty in Mexico based on official data from the Ministry of Social Development (SEDESOL) differentiating between three groups from the bottom to the top. The bottom group is associated with the notion of nutritional poverty. The middle group, defined as resource poverty, includes all people classified under nutritional poverty, together with those lacking access to basic health and education services. The top group defined as monetary poverty encompasses the population suffering nutritional 


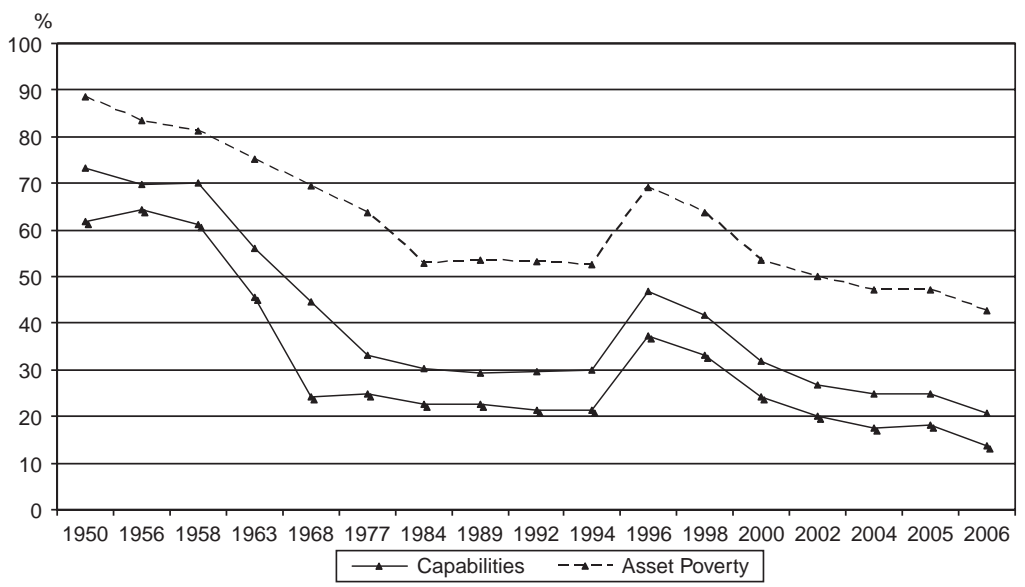

Figure 4 Poverty in Mexico, 1950-2006 (percentage of total population) Source: Székely (2005) and CONEVAL.

Note: The tree lines represent, from bottom to top: food poverty, poverty in access to basic services and poverty of overall resources.

and asset poverty, and also covers individuals with incomes insufficient to meet clothing, housing and public transportation needs.

From 1950 to 2006 there is a decline in the percentage of the population living in poverty, as measured by the three different indicators, though with periods of drastic change. From 1950 to the early 1980s - when the economy was following a strategy of state-led industrialization and ISI - the three indicators of poverty show a significant fall. This reduction was interrupted in the aftermath of the collapse of the oil bonanza in the mid-1980s. From then onwards, until the mid-1990s, there was virtually no advance in tackling poverty. This is not surprising given that in this period the Mexican economy remained practically stagnant.

Moreover, the crisis in 1995, when real GDP in Mexico shrank by almost 7 per cent, had a brutal impact on the socioeconomic conditions of a large proportion of the Mexican population. In fact by 1996 the incidence of poverty, as measured by each of the three distinct indicators, jumped more than fifteen points relative to its level in 1994, reaching levels comparable to those of the early 1960s. In 2000-6, moderate economic growth combined with an increase in the percentage ratio of the economically active population has led to a reduction of poverty (see Table 3 ). The rural areas, where most poor people are located, saw a decline in the three indicators of poverty from 2000 to 2006, and the same trend is evident in urban areas. At the national level, over these five years, the proportion of the population with nutritional poverty fell nearly ten points, that in poverty of access also fell about ten points and the resource poverty rate slightly more. ${ }^{11}$ 
Table 3 Urban, rural and national poverty in Mexico, 2000-6

\begin{tabular}{lcccc}
\hline & \multicolumn{4}{c}{ Percentage } \\
\cline { 2 - 5 } & 2000 & 2002 & 2004 & 2006 \\
\hline National & & & & \\
Nutritional poverty & 24.1 & 20.0 & 17.4 & 13.8 \\
Poverty of access & 31.8 & 26.9 & 24.7 & 20.7 \\
Resource poverty & 53.6 & 50.0 & 47.2 & 42.6 \\
Rural & & & & \\
Nutritional poverty & 42.4 & 34.0 & 28.0 & 24.5 \\
Poverty of access & 49.9 & 42.6 & 36.2 & 32.7 \\
Resource poverty & 69.2 & 64.3 & 57.4 & 54.7 \\
Urban & 12.5 & 11.3 & 11.0 & 7.5 \\
Nutritional poverty & 20.2 & 17.2 & 17.8 & 13.6 \\
Poverty of access & 43.7 & 41.2 & 41.1 & 35.6 \\
Resource poverty & & & \\
\hline
\end{tabular}

Source: Elaboration with data of CONEVAL: www.coneval.gob.mx/coneval/program meas\%20pobreza/Cuadros\%20de\%20resultados.xls.

\section{Inequality}

Income distribution - as measured by the Gini coefficient - has been showing a long-term improvement since 1950, but with a U-pattern somewhat different from that of poverty (see Figure 5). In the 1950s to the early 1960s, income distribution became more concentrated. From then until the mid-1980s income was distributed more evenly, but the trend changed again when trade liberalization and macroeconomic reforms began to be implemented. For the next fifteen years, a more concentrated pattern of income is indicated. By 2004 the Gini stood at 0.46 , which is above that reached in 1984 and above the world average (0.40). In addition, as in most developing countries, in Mexico the concentration of wealth is much higher than that of income. Such a high concentration of income is alarming taking into account the vast proportion of the population living under conditions comparable to those prevailing in much poorer countries.

This inequality in income distribution is also reflected regionally. On the one hand, the federal entities (estados) in the south are typically much poorer than those in the north. On the other, there is also considerable intra-state inequality, with acute differences in income and socio-economic indicators even within the same state, a difference that is frequently associated with rural-urban polarization. Such differences are mirrored to some extent in the indicators of access to basic services, health and schooling and in general human development indicators (UNDP, 2004).

Mexico also shows a somewhat strong and inverse correlation between economic growth and poverty. ${ }^{12}$ In other words, in the last forty years, periods of 


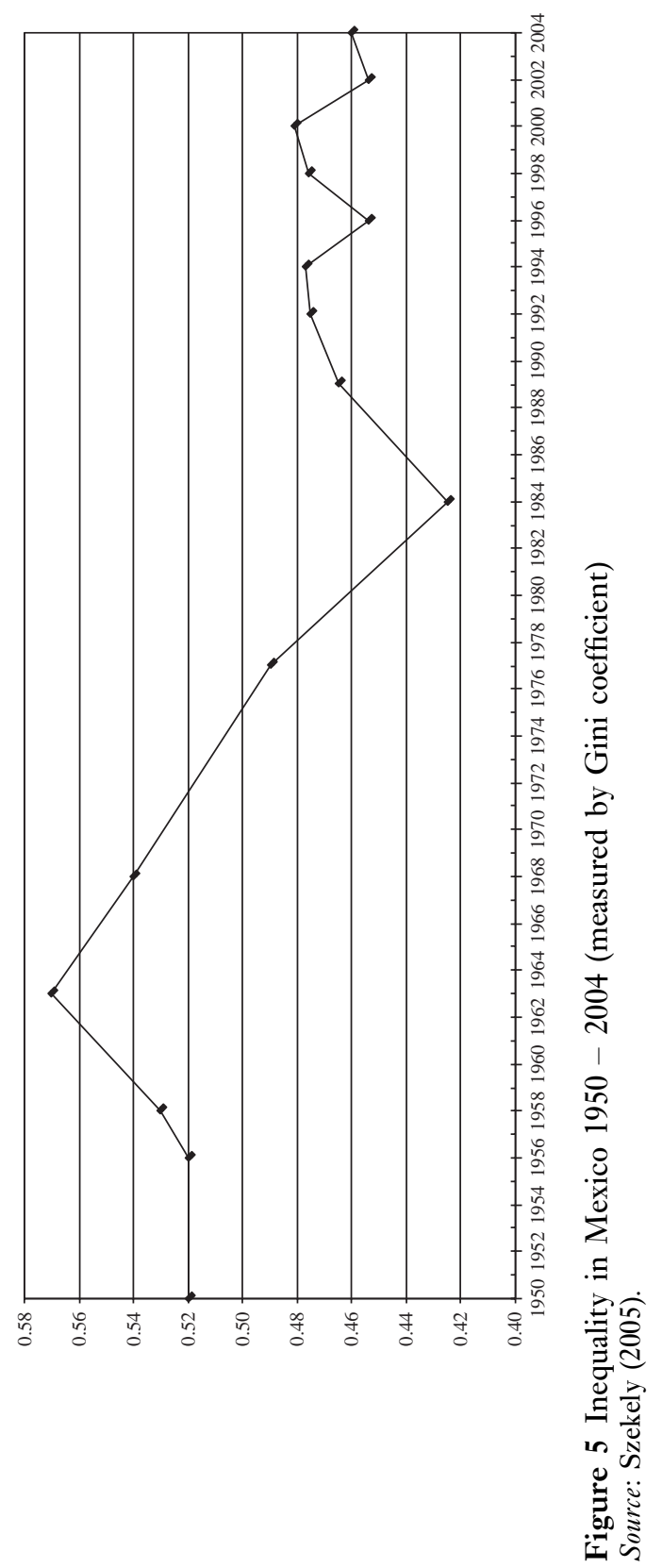


strong economic expansion have tended to be associated with a more progressive distribution of income and a decrease in poverty. Moreover, episodes of balance of payment crisis and drastic contractions of economic activity have caused a sharp deterioration in the living conditions of the population, dramatically increasing the incidence of poverty and widening the gap between the haves and the have-nots. Particularly worrying is the fact that the adverse impacts on poverty due to economic crisis have not been fully compensated for by the effects of the subsequent resumption of economic growth. Thus, the volatility of economic growth has had an adverse and significant impact on the poor. This ratchet effect has implied, for example, that, even though Mexico's real per capita income in 2000 was 20 per cent higher than in 1984, the percentage of those in poverty for both years was very similar (see Uthoff, 2007).

There is a consensus that in Mexico trade liberalization has been a significant force behind the increase in inequality in the last twenty years. ${ }^{13}$ Indeed, it did contribute to the widening of the wage gap between skilled and unskilled workers. In addition, it also contributed to reducing the income elasticity of employment given that the economy's most dynamic sectors became highly dependent on the use of imported inputs, thus weakening their backward linkages.

In brief, approximately twenty-five years of neo-liberal reforms in Mexico have been accompanied by a reduction, albeit insufficient, in poverty and an increase in income inequality in the overall context of an economy marked by low rates of inflation and fiscal deficits and a slow rate of expansion. Part of the reason for such insufficient progress in social development in the last decades is the failure of the economy to enter a path of long and sustained expansion. It is important to examine to what extent this insufficient social advance is or is not linked to the evolution of the social policies implemented since the shift towards a neo-liberal development agenda. Moreover, as Moreno-Brid and Ros (in press) and recently the OECD show, the reduction in poverty in the last ten years, achieved in the midst of a laggardly performance by the Mexican economy, is actually a result of the 'demographic bonus'. Indeed, as we have stated in some of our previous work, a major cause of the decline in poverty in Mexico during this period is the rise in the ratio of economically active population; more precisely, in the average number of people employed per household, and not so much by an improvement in average real remunerations or by the effect of income transfers.

\section{Conclusions}

After more than twenty years of neo-liberal reforms the lack of robust economic growth has plainly become a major obstacle for social development. Among the reasons behind this failure stand the elimination of industrial policies, the reduction in public investment and the tendency of the real exchange rate to rise, all factors which have become common features of 
Mexican policy. As long as strong economic growth and job creation are wanting, social policies, whether targeted or not, will be unable to bring about major improvements in poverty and inequality indicators.

Mexico's structurally weak fiscal situation was left uncorrected by the macroeconomic reforms of the 1990s. As noted, fiscal revenues represent a small proportion of GDP, in terms of international comparisons. Even more worrying, between 30 per cent and 40 per cent is derived from oil income. Such an under-funded state will find it increasingly difficult to improve the social and economic conditions of the poor not only in remote rural areas but also in urban areas. Starved of resources, the Mexican state increasingly runs the risk of being unable to maintain the minimum functionality of its key institutions and may begin to experience an erosion of its effectiveness and legitimacy.

For Mexico, as well as for emerging economies in general, the reduction of poverty and inequality is not only an ethical matter, but also a prerequisite for achieving a high rate of economic expansion. The neglect of these issues affects not only the poor but also the middle classes who have become increasingly frustrated by their unfulfilled expectations of improving, or at least maintaining, their standard of living. Large proportions of Mexico's middle class believe that their standard of living is lower than that of their parents, and fear that their own children will face still harsher economic conditions.

The magnitude of Mexico's development challenge is such that it requires a new social pact to engage the key political actors and economic and social agents committed to actively supporting it. Dealing with poverty and equality as secondary problems, detached from democratic processes and citizenshipbuilding, will in all likelihood also fuel trends of political alienation, anomie and social disintegration. Social policy cannot be divorced either from economic policies and objectives or from the new demands for citizenship that call for increased diversity in the provision of welfare programmes, and call for more efficient and effective action by welfare services, particularly in health, education and social security. At the same time however, the principle of universal basic coverage and security should not be renounced. In essence this entails some compromise between efficiency and universalism which leaves some scope for targeted interventions. Beyond these key criteria is the question of how to decide the state's legitimate role in articulating and solidifying social cooperation as the basis of an integrated welfare state, instead of the truncated one that currently exists. We must approach this task through building new forms of solidarity from new or renewed social capital that connects communities, regions, cities and local governments with the state. This implies overcoming the current gulf between social and economic policies.

Mexico's economic growth is closely tied to circumstances beyond its national borders. With 88 per cent of its exports destined for US markets, the fortunes of economic growth and employment will be deeply affected by the performance of the US economy. To what extent Mexico's productive structure can be modernized if the process of integration with the US economy continues, and whether it will diversify to other markets in Europe 
and Asia, are open questions. For some analysts, the road ahead is the currently far from any realistic possibility of adopting a regional economic development agreement with the US on the lines inspired by the European Union. Others point instead to the need to diversify Mexico's trade and investment markets, seeking greater synergies with Asia (especially China) while relying much more on developing domestic and regional markets. In any case, as the displaced population from the traditional agricultural system look for job opportunities beyond their locality, illegal emigration to the US will continue to be an obvious choice, albeit with declining rewards under present economic conditions.

Returning to the points raised at the beginning of this article, it seems that economic policy should aim to achieve not only a low rate of inflation and balanced fiscal accounts, but, above all, a high and sustained rate of economic expansion, matched by adequate job-creation rates in terms of number and quality. High and variable inflation should certainly be avoided, but 'stop and go' patterns of economic expansion that result in an average real GDP growth rate well below its potential trajectory must be avoided. Finally, Mexico urgently needs to integrate social and economic policy so that the short and long-run objectives of the latter - regarding, inter alia, inflation and economic growth - are tied to selected indicators of social development. One option would be to establish minimum levels of satisfaction of certain key basic needs, based on selected indicators of human or social development, and to condition macroeconomic policies to guarantee their satisfaction independently of the economic cycle. Such measures would establish a floor for human capital and automatic stabilizers for fiscal policy management. This would exert a countercyclical influence on economic activity, similar to that achieved by the introduction of the unemployment benefit in developed countries. The level and scope of such basic needs would have to be politically determined and fully backed by a social pact that achieved agreement of the relevant political and economic actors and of society as a whole. An indispensable input for this approach is a fiscal reform that aims, simultaneously, at ensuring a significant increase in non-oil public revenues as well as the adoption of mechanisms to monitor their transparent and efficient use to promote economic and social development. Building this social pact is perhaps Mexico's greatest challenge.

\section{Acknowledgements}

The opinions here expressed are the authors' own and do not necessarily coincide with those of their employers, in particular those of the United Nations Organisation. The authors gratefully acknowledge the suggestions of Maxine Molyneux, Diego Sánchez, Juliana Martínez Franzoni and Gerardo Bracho Carpizo as well as the comments of the participants at the Conference on Social Policy, Economic Development and Income Inequality, Institute for the Study of the Americas, University of London, 31 May-1 June 2007. 


\section{Notes}

1 We are grateful to one anonymous referee for having suggested this metaphor to illustrate the daunting challenge of social policies in the neo-liberal era: trying to avoid a deterioration of the living conditions of the poor provoked to a large extent by the incapacity of these reforms to usher in a new phase of high and sustained expansion of output and employment.

2 The most successful programmes during this period were in the auto industry, computerware and pharmaceuticals (Moreno-Brid, 1999).

3 In 1982, the peak year of Mexico's strategy of ISI and state-led industrialization, there were 1115 public enterprises. These enterprises had operations in forty-one out of a total of forty-nine branches of economic activity. Some of these forms had significant market power (Moreno-Brid, 1999) and carried out investment projects that the private sector could not or would not undertake. By 1994 only seventy such enterprises remained active.

4 These systems are sometimes defined as 'truncated welfare states, because the majority of the population especially the poor do not receive those benefits' (See Díaz Cayeros et al., 2008).

5 When NAFTA negotiations started in 1990 Mexico was one of the economies most open to foreign trade (OECD, 1992).

6 As Díaz Cayeros et al. (2008) point out, conditional cash transfer programmes have various advantages: 1) effectiveness in targeting the poor, 2) immediate as well as longer-term impacts on poverty (the first is due to the cash transfer mechanism that augments the household's disposable income, the second is associated with the increased technical, nutritional and health conditions in the family) and 3) constraining the discretionary power of politicians to tailor the funds for poverty alleviation according to other needs. But these programmes also have major limitations given that they: 1) fail to reach a significant group of the extreme poor who live far away from clinics or schools, 2) have insufficient funds given the magnitude of the challenge of poverty alleviation and 3) have an uncertain impact on the employment-generating capacities of their beneficiaries. Moreover when the quality of the educational services of the poor is not up to par, the merits of such programmes may be questionable.

7 For a recent, comprehensive analysis of Mexico's social policy in recent decades, see Cordera and Cabrera (2007).

8 The upward trend in social spending is also evidenced when measured in constant US dollars in absolute as well as in per capita terms (see CEPAL, 2004).

9 In addition, the main international financial organizations began increasingly to condition their financial support on the drafting of poverty reduction strategy programmes (PRSP).

10 For an in-depth critique of Oportunidades, see Boltvinik (2004).

11 SEDESOL argues that these changes are the result of: 1) a slight improvement in real incomes; 2) increased macroeconomic stability; 3) an expansion of social programmes such as Oportunidades; and 4) an increase in the value of family remittances, i.e. money orders sent home by Mexican workers in the United States. In 2006 , family remittances from abroad exceeded US $\$ 23$ billion, most of it sent to rather low-income population.

12 See Uthoff (2007) for a recent comparative analysis of the evolution of poverty and inequality in Mexico within the Latin American context.

13 For an interesting and recent illustration of the evolution of inequality after trade liberalization in Mexico and in other Latin American countries see Davis et al. (2007). 


\section{References}

Behrman, J., Sengupta, P. \& Todd, P. (2002). Progressing through PROGRESA: An impact assessment of a school subsidy experiment. Paper presented at the first meeting of the Social Policy Monitoring Network, 'Conditional Cash Transfers Programs', Research Department, Inter-American Development Bank. Boltvinik, J. (2004). Políticas focalizadas de combate a la pobreza en México: El PROGRESA/OPORTUNIDADES. In J. Boltvinik \& A. Damián, (Eds.), $L a$ pobreza en México y el mundo. Realidades y desafiós. Mexico: Siglo XXI Editores.

Boltvinik, J. (2006). Fortalecer lo social frente a lo económico. Economía Moral:

La Fornada, 3 March.

Cabrera Adame, C. J. (2007). Pobreza y desigualdad. Economía Informa, 343.

Facultad de Economía, UNAM.

CEPAL (2004). Panorama social de América Latina. Santiago: United Nations.

Clavijo, F. (Ed.) (2000) Reformas económicas en México 1982-1999. Lecturas del Trimestre Económico 92. Mexico City: Fondo de Cultura Económica.

Cordera Campos, R. \& Cabrera Adame, C. J. (Eds.) (2007). La politica social en México: Tendencias y perspectivas. México: UNAM.

Cruz, C., de la Torre, R. \& Velázquez, C. (2006). Informe compilatorio.

Evaluación externa de impacto del Programa Oportunidades 2001-2006. Cuernavaca, Mexico: Instituto Nacional de Salud Pública.

Davis, B., Lyons, J. \& Batson, A. (2007). Unexpected results: Globalisation has widened income disparity. Wall Street Journal, 24 May.

de Janvry, A. \& Sadoulet, E. (2006).

Making conditional cash transfer programs more efficient: Designing for maximum effect of the conditionality.

World Bank Economic Reviem, 20, 1-29.

Diaz Cayeros, A., Estévez, F. \&

Magaloni, B. (2008). Strategies of vote buying: Social transfers, democracy and welfare in Mexico. Unpublished manuscript.
Government of Mexico (2004). Ley general de desarrollo social y reglamento de la ley general de desarrollo social. Diario Oficial de la Federación. Moreno-Brid, J. C. (1999). Reformas macroeconómicas e inversión manufacturera en México. Serie Reformas Macroeconómicas No. 47, ECLAC, Santiago, Chile. Moreno-Brid, J. C. (2001). Essays on economic growth and the balance of payments constraint with special reference to the case of Mexico. $\mathrm{PhD}$ thesis, University of Cambridge, Cambridge, UK.

Moreno-Brid, J. C. (2002). Testing the balance-of-payments constrained growth model: The Mexican economy 1967-99. In P. Davidson (Ed.), A post keynesian perspective on 21st century economic problems. Cheltenham: Edward Elgar. Moreno-Brid, J. C. \& Ros, J. (in press). Development and gromth in the Mexican economy: A historical perspective. New York: Oxford University Press.

OECD (1992). Mexico: Economic studies of the OECD. Paris: Organization for Economic Cooperation and Development. OECD (2003). OECD economic surveys: Mexico. Paris: Organization for Economic Cooperation and Development.

OECD (2004). Learning for tomorrow's world: First results from PISA 2003.

OECD.

Pacheco-López, P. (2005). The impact of trade liberalisation on exports, imports, the balance of payments and growth: The case of Mexico. Fournal of Post Keynesian Economics, 27(4), 595-619.

Rogozinsky, J. (1996). La privatización de empresas paraestatales: Una visión de la modernización. Mexico City: Fondo de Cultura Económica.

Ros, J. (1994). Mexico's trade and industrialization experience since 1960: A reconsideration of past policies and assessment of current reforms. In G. Helleiner, (Ed.), Trade policy and industrialization in turbulent times. London: Routledge.

Székely, M. (2005). Pobreza y desigualdad en México entre 1950 y 2004. 
Serie Documentos de Investigación, SEDESOL, No. 4, July.

UNDP (2004). Informe sobre Desarrollo Humano México 2004. Oficina Nacional de Desarrollo Humano, PNUD-Mexico.
Uthoff, A. (2007). Reducción de la pobreza $e$ inequidad. Paper presented at the Foro de Políticas Públicas para México, ECLAC.

Juan Carlos Moreno-Brid has held the position of Research Coordinator of the Subregional Office in Mexico of the Economic Commission for Latin America and the Caribbean (ECLAC), United Nations Organization, since 2003. Before joining the United Nations he worked as a research associate at the David Rockefeller Center for Latin American Studies, Harvard University. He has published more than fifty papers, as well as book chapters, on Latin American economic and social development issues in academic journals, including: World Development, Development and Change, Revista de la CEPAL, Metroeconomica, Cuadernos del SELA, Investigación Económica, Banca Nazionale del Lavoro Quarterly Reviem, International Fournal of Political Economy, Journal of Post Keynesian Economics, International Reviem of Applied Economics, Harvard Reviem of Latin America, Cuadernos del SELA, Nueva Sociedad, Revista Mexicana de Sociologiá, Economía Mexicana, Cambio and Comercio Exterior.

Juan E. Pardinas has been a consultant for the Mexican Institute for Competitiveness (IMCO), a non-profit institution that aims to generate public policy proposals for Mexico's development and economic growth, since 2007. He has been a consultant for the ECLAC, the IADB, the Mexican Ministry of Finance and the Instituto Libertad y Democracia en Peru. He writes a weekly op-ed column in the newspaper Reforma. He has taught at the London School of Economics and the Instituto Tecnológico Autónomo de México (ITAM). From 1999 to 2007, he was a researcher at the Centro de Investigación para el Desarrollo, CIDAC, based in Mexico City. He has authored two books and seven book chapters on topics related to Mexico's political economy.

Jaime Ros, a professor of economics at the University of Notre Dame and fellow of the Kellogg Institute for International Studies, specializes in development economics with special reference to Mexico and Latin America. His most recent book is Development theory and the economics of gromth (University of Michigan Press, 2000). His articles have appeared in the Cambridge Journal of Economics, World Development, Journal of Development Studies, The Manchester School of Economic and Social Studies, El Trimestre Económico, Desarrollo Económico and other scholarly journals and edited books. Current projects include an edited handbook, with Amitava Dutt, on development economics as well as a book on the history of Mexico's economic development with Juan Carlos Moreno-Brid. 